\title{
Nova lei do empregado doméstico espanhol: um contributo ao direito comparado*
}

\section{Nueva ley española interno del empleado: una contribución al derecho comparado}

João Ernesto Paes de Barros ${ }^{1}$

\section{Resumo}

O objetivo do presente artigo é fazer uma analise comparada dos principais aspectos direitos do emprego doméstico dispostos na nova regra espanhola (janeiro de 2012) comparando-o ao direito brasileiro. A motivação para o presente artigo está na curiosidade científica da evolução do pensamento jurídico, considerando que os dois países demoraram muito para aproximar os direitos dos empregados domésticos das demais categorias. $\mathrm{O}$ mérito deste artigo sustenta-se na contribuição para a discussão do insustentável desequilíbrio de direitos e garantias que existe entre os trabalhadores domésticos em relação aos demais trabalhadores. Desta forma, sendo o Real Decreto espanhol uma nova regra é relevante observar as inovações e nuanças que esse novo marco legal sinaliza para as relações laborais.

Palavras-chave: Empregada doméstica. Direitos trabalhistas. Estudo comparado. Direitos e deveres.

\section{Resumen}

El objetivo de este trabajo es realizar un análisis comparativo de los principales aspectos de los derechos laborales en la regla nueva del empleado del hogar (enero 2012), comparándolo con la legislación brasileña. La motivación de este artículo está en la curiosidad científica de la evolución del pensamiento jurídico, teniendo en cuenta que los dos países tomaron demasiado tiempo para tornar efectivo los derechos de los trabajadores del hogar en relación a las otras categorías. El objeto de este artículo no es la elaboración exhaustiva y minuciosa, bajo el punto de vista teórico, pero el mérito basa en la contribución a la discusión del desequilibrio insostenible de los derechos y garantías que existe entre los trabajadores domésticos en relación con los demás trabajadores. Por lo tanto, al ser una nueva regla es indispensable observar las innovaciones y matices que señala este nuevo marco legal para las relaciones laborales.

Palabras-clave: Empleada del hogar. Derechos laborales. Estudios comparados. Derechos y deberes. 


\section{Introdução}

Historicamente os trabalhadores domésticos do Brasil e da Espanha possuíam menos direitos trabalhistas que a maioria das demais categorias. No Brasil, os empregados domésticos só tiveram seus direitos deferidos em 1972 com a regulamentação da categoria, mediante a promulgação da Lei No 5.859, de 11 de Dezembro de 1972, uma vez que a Consolidação das Leis do Trabalho (CLT) de 1943 de forma expressa excluiu os trabalhadores domésticos da regra consolidada ${ }^{2}$.

Na Espanha, semelhantemente, a primeira regra dos empregados domésticos veio com o Real Decreto 1424 de $1985^{3}$. Este decreto foi muito criticado pelos sindicatos e associações por regulamentar situações laborais desfavoráveis à uma categoria composta em sua maioria por mulheres.

A partir de 01 de janeiro de 2012, na Espanha passou a vigorar a nova lei para os empregados domésticos ${ }^{4}$ trazendo novos direitos. Desta forma, com este artigo pretende-se contribuir mediante análise comparada do regramento que disciplina o trabalho dos empregados domésticos no Brasil e na Espanha.

No direito espanhol, o conjunto de regras que regula a atividade laboral dos trabalhadores é o Estatuto dos Trabalhadores ${ }^{5}$ de 1995 com atualizações. Nele, a prestação de serviço doméstico, é tida e havida como uma relação laboral de caráter especial, nominando-a de serviço do lar familiar. Esta relação laboral especial foi inicialmente regulamentada pelo Real Decreto 1424/1985, tendo em vista as condições particulares de prestação de serviço e dos trabalhadores que se submetem ao serviço doméstico.

2 "Art. 70 Os preceitos constantes da presente Consolidação salvo quando for em cada caso, expressamente determinado em contrário, não se aplicam: a) aos empregados domésticos, assim considerados, de um modo geral, os que prestam serviços de natureza não-econômica à pessoa ou à família, no âmbito residencial destas;". BRASIL. Consolidação das leis do trabalho. 1843. Disponível em:< http://www.planalto.gov.br/ ccivil_03/decreto-lei/Del5452.htm>. Acesso em: 19 fev. 2012.

3 ESPANHA. Boletín Oficial del Estado, n.193, 13 ago. 1985. Disponível em:<http://www.boe.es/aeboe/consultas/bases_datos/ doc.php?id=BOE-A-1985-17108>. Acesso em: 19 fev. 2012.

4 ESPANHA Real Decreto $\mathrm{n}^{\circ} 1.620$ de 14 de novembro de 2011. Boletim Oficial do Estado, n. 277, Seção. I,. p. 119046, 17 nov. 2011
No Brasil, por outro lado, o direito dos domésticos foi regulado pela Lei $\mathrm{n}^{\circ} 5.859$, de 11 de dezembro de 1972, com modificações posteriores, em especial da Constituição Federal de 1988 que, por sua vez, acrescentou novos direitos sociais, notadamente os direitos veiculados no artigo $7^{\circ}$, a saber: salário mínimo ( art. 7º, inciso IV); irredutibilidade do salário (art.7º, inciso VI); décimo terceiro salário (inciso VIII); repouso semanal remunerado (inciso XV); férias anuais remuneradas (inciso XVII); licença à gestante (inciso XVIII); licença paternidade (inciso $\mathrm{XIX);} \mathrm{aviso-prévio} \mathrm{(inciso} \mathrm{XXI);} \mathrm{e} \mathrm{aposentadoria} \mathrm{(inciso}$ XXIV). Em 2006, no Brasil foi promulgada Lei 11.324, trazendo novos direitos à "empregada doméstica"6 com as seguintes possibilidades: contribuição patronal à Previdência Social; proibição de descontos no salário do empregado por fornecimento de alimentação, vestuário, higiene ou moradia; direito a férias anuais remuneradas de 30 (trinta) dias com, pelo menos, 1/3 (um terço); e a dispensa arbitrária ou sem justa causa da empregada doméstica gestante.

\section{Os direitos e obrigações dos domésticos estabelecidos pelo Real Decreto espanhol:}

\subsection{Acesso ao trabalho}

Pela nova regra os empregadores podem contratar empregados domésticos diretamente ou por intermédio de agências públicas de emprego ou de recrutamento que disponibilizem os nomes dos candidatos às vagas. Neste procedimento de escolha, está garantido o princípio da igualdade de acesso ao emprego, proibindo às agências públicas de emprego ou de recrutamento, qualquer discriminação em razão de origem racial ou étnica, sexo, idade, estado civil, religião ou crença, opinião política, orientação sexual, filiação sindical, status social, linguagem/dialeto ou por ser portador de necessidade especial, desde que o trabalhador seja capaz de fazer o trabalho com as habilidades que se requer ${ }^{7}$.

Na Lei no 5.859/1972 (Lei do Empregado Doméstico Brasileiro) não há qualquer disposição sobre o acesso ao trabalho. Contudo, a Constituição Federal de 1988,

\footnotetext{
6 BRASIL. Lei $n .^{\circ} 11.324$, de 19 de julho de 2006. Disponível em: < http://www.planalto.gov.br/ccivil_03/_ato2004-2006/2006/ lei/111324.htm>. Acesso em: 06 fev. 2012.

7 Real Decreto no. 1620/2011, Espanha, 4.2.
} 
garantiu a todos os trabalhadores no Art. $7^{\circ}$, inciso XXXI a "proibição de qualquer discriminação no tocante a salário e critérios de admissão do trabalhador portador de deficiência”.

\subsection{Contrato de trabalho escrito}

Semelhantemente ao direito brasileiro, na Espanha o contrato pode ser escrito ou verbal, contudo pelo Real Decreto passou a ser direito do empregado a exigência do contrato, a qualquer momento da relação laboral, bem como pela regra tornou-se imprescindível a formalização da relação de trabalho, pois é de responsabilidade do empregador a comunicação da ativação do trabalhador na Tesouraria da Segurança Social e do Trabalho. Caso o empregador não firme o contrato com o doméstico e comunique a Tesouraria aplica-se a presunção de que o contrato fora celebrado por tempo indeterminado e em tempo integral, alem das penalidades administrativas cabíveis ${ }^{8}$.

No Brasil a Carteira de Trabalho e Previdência Social (CTPS) é o meio de prova do contrato de trabalho. Inicialmente chamava-se exclusivamente Carteira Profissional, porém com o advento do Decreto Lei no 926/699, passou a chamar-se Carteira de Trabalho e Previdência Social. O empregador deverá anotar na CTPS a data de contratação, identificação do empregador, salário a ser pago, e poderá obter na agencia do INSS o número de identificação da previdência (NIT) uma vez que é facultativo ao empregado doméstico.

Neste ponto é interessante observar que a Espanha filia-se a teoria contratualista impondo ainda, a obrigatoriedade ao empregador de registrar na tesouraria da Previdência Social a avença pactuada. Porém no Brasil há divergência quanto a natureza jurídica da CTPS em razão da teoria contratualista e anticontratualista ${ }^{10}$. Contudo é consenso no Brasil da utilização da CTPS e da sua finalidade:

- probatória, pois que evidencia a existência de um contrato; $\mathrm{e}$

\footnotetext{
8 ESPANHA. Real decreto $n^{\circ} 1.620$, de 14 de novembro de 2011. mimeo. Art. 5.1, 2 e 4.

9 BRASIL. Senado Federal. 1969. Disponível em: <http:// www6.senado.gov.br/legislacao/DetalhaDocumento. action?id=119362>. Acesso em: 6 fev. 2012.

${ }^{10}$ MOSCHIN JÚNIOR, Alberto José. Forma de Pactuação e Prorrogação do Contrato de Experiência. Revista Eletrônica da Faculdade de Direito de Franca, Franca, v. 2, n. 1, 2010. Disponível em: $<\mathrm{http}: / / \mathrm{www}$. revista. direito franca. br/index. php/refdf/article/viewFile/63/34>. Acesso em: 2 fev. 2012.
}

- constitutiva, pois as anotações realizadas constituem prova em favor do empregado, excetuando as situações que decorrem algum tipo de vicio jurídico.

Em caso de contratação verbal ${ }^{11}$, o Real Decreto espanhol prevê, salvo prova em contrário, que o contrato de trabalho será considerado celebrado por tempo indeterminado e sua jornada completa se ele dura mais de quatro semanas, salvo prova em contrário. Assim, se o contrato de prestação de serviço doméstico exceder a quatro semanas deve ser feito por escrito. No que pese o legislador não ter estabelecido a obrigatoriedade do contrato de forma mais incisiva, atribuiu, via presunção de direito, as situações mais benéficas ao empregado, considerando sempre tempo indeterminado, jornada completa e remuneração integral.

Segundo Rey Guanter ${ }^{12}$ qualquer que seja a modalidade do contrato (verbal ou escrito) ou sua duração, se não estabelecido por escrito se presumirá celebrado por um ano, prorrogando-se tacitamente por período igualmente anual, o que trará maior beneficio ao empregado relativo à verbas indenizatórias, que são maiores.

Como o contrato pode ser exigido pelo doméstico, a nova regra concedeu prazo para regularizar os contratos em curso, firmados anteriormente a este Real Decreto, estabeleceu o prazo para até 30 de junho para regularizar os contratos aos moldes desta regra.

\section{Direito de informação das condições de trabalho.}

Um aspecto de avanço na relação laboral domestica diz respeito à clareza de informações dos serviços a serem prestados e a regulação do seu tempo, no contrato.

Nesta nova regra espanhola ${ }^{13}$ o trabalhador doméstico tem o direito de ser informado de todos os elementos essenciais da sua prestação de serviço, tais como: salário em espécie; duração da jornada diária com seus momentos de ativação e descanso; atividades a serem desenvolvidas; o sistema de remuneração ou compensação dessas horas, bem como as regras da casa no caso de pernoite do doméstico. É importante destacar que o doméstico deverá ter definido com precisão o horário de

${ }^{11}$ ESPANHA. Real Decreto $n^{\circ}$. 1620/2011. Mimeo. Art. 5.1

${ }^{12}$ REY GUANTER, Salvador del. Estatuto dos Trabajadores: comentado y con jurisprudência. 2. ed. Madrid: La Ley, 2007. p. 82.

${ }^{13}$ ESPANHA. Real Decreto $n^{\circ}$. 1620/2011. Mimeo. Art. 5.4 
trabalho e de descanso intrajornada e o horário final das atividades diárias.

A regra espanhola induz a um controle metódico mas não exaustivo das atividades, no sentido de garantir tanto para empregador quanto ao empregado a certeza dos momentos do labor, do descanso e das horas extras. No contrato deverá constar o que poderá (ou não) fazer o doméstico; e para os internos (os que pernoitam) de forma objetiva os espaços que poderá visitar no ambiente comum do lar; o uso dos espaços comuns (cozinha, banheiro, sala, terraço) após sua jornada diária. Desta forma, o empregado e o empregador têm a certeza jurídica de suas respectivas obrigações e direitos.

O direito de informação das condições do trabalho, das atividades, metas e objetivos, correspondem a um mecanismo de garantia das duas partes contratantes, que propiciariam o melhor acordo de intenções na relação laboral. Assim, subjaz ao direito de informação, o principio da dignidade da pessoa humana e o princípio da boa fé.

Na Cidade de Burgos, Espanha, vários organismos de assistências aos trabalhadores mais vulneráveis ${ }^{14}$ reuniram-se para elaborar uma "plataforma comum" ajustando condições e valores remuneratórios mais favoráveis aos trabalhadores domésticos que forem contratados por intermédio desses organismos.

$\mathrm{Na}$ legislação brasileira aplicada ao doméstico não consta nenhuma regulação especifica ao doméstico quanto ao direito de informação, dando azo ao abuso e desrespeito ao princípio constitucional da dignidade da pessoa humana.

O empregado doméstico não tem direito às horas extras. Com base no parágrafo único do artigo $7^{\circ} \mathrm{da}$ Constituição Federal, esta categoria não está contemplada com a jornada de trabalho de 44 horas semanais prevista no inciso XIII, nem com o direito à remuneração por serviço extraordinário do inciso XVI. Assim, como Constituição Federal não estabeleceu o limite da jornada de trabalho do empregado doméstico, não caberá ao judiciário fazê-lo compelindo o empregador a uma obrigação que o ordenamento jurídico não lhe impõe.

${ }^{14}$ CARITAS, C.V.S., BURGOS ACOGE, ATALAYA, FUNDACIÓN CAUCE, CRUZ ROJA, FUND. SECRET. GITANO, ASOC. LA RUEDA, RED MUJER EMPLEO JCYL e ACCEM.
Contudo, a 14 a Turma do Tribunal do Trabalho de São Paulo (TRT/SP - 01403004120095020058) deferiu direito à hora extraordinária, com o seguinte fundamento:

A Constituição da República Federativa do Brasil tem como fundamento básico o princípio da dignidade humana. A negativa de limitação de jornada ao trabalhador doméstico e de pagamento adicional por horas extraordinariamente laboradas é retrocesso social, vez que o parágrafo único do artigo sétimo do Texto Maior não pode ser interpretado como forma de marginalização do empregado doméstico, mas sim como garantidor de direitos mínimos. A ausência de lei especial que regulamente jornada e remuneração adicional pelo trabalho extraordinário do trabalhador doméstico impõe ao julgador o dever de aplicar norma geral ao trabalhador diferenciado, de forma analógica, nos termos do artigo oitavo da CLT, a fim de cumprir com seu dever de distribuir justiça.

Tal entendimento encontra respaldo em inúmeros artigos científicos relacionados ao tema dignidade humana e direito laboral ${ }^{15}$, dos quais se destaca, pela concisão:

O Direito é um mecanismo a serviço da justiça e do bem comum, que abrange a atividade do legislador, do intérprete e do aplicador, os quais devem levar em conta, sempre, certos valores assegurados no ordenamento jurídico. No caso, esses valores estão na Carta Magna, que dispõe no art. $1^{\circ}$ como fundamentos da nossa República e do Estado Democrático de Direito, entre outros, a cidadania, a dignidade da pessoa humana e os valores sociais do trabalho. $\mathrm{O}$ art. $170 \mathrm{diz}$ que a ordem econômica funda-se na livre iniciativa e na valorização do trabalho humano ${ }^{16}$.

É muito comum no Brasil os trabalhadores domésticos internos ativarem por 13 a 16 horas diárias e ainda tralharem sábados e domingos. Portanto pelo atual entendimento de que o doméstico não faz jus às horas extraordinárias, não teria sentido algum o interesse de se registrar os horários de trabalho, pois de qualquer forma os intervalor e os descansos entre jornadas e de finais de semana, ficariam ao influxo da relação de bom senso, necessidade e oportunidade do empregador.

${ }^{15}$ Cf. PIMENTEL, Dinaura Godinho. Direito do trabalho e dignidade da pessoa humana, no contexto da globalização econômica problemas e perspectivas. São Paulo: LTr, 2005; RODRIGUES, Américo Plá. Princípios do direito do trabalho. 3 ed. São Paulo: LTr, 2002; FERREIRA FILHO, Manoel Gonçalves. Curso de Direito Constitucional. 24 ed. São Paulo: Saraiva, 1997, entre outros.

${ }^{16}$ MELO, Raimundo Simão de. Acidente de trabalho: responsabilidade com e sem culpa. Escola da Magistratura, São Paulo, Ano 3, n. 3, p. 103, 2008. 


\subsection{Direito ao contrato por período de experiência}

Em ambos os países o contrato por período de experiência está regulada pela regra comum dos trabalhadores, na CLT ${ }^{17}$ no parágrafo único do Artigo $445 \mathrm{e}$ no Estatuto dos Trabalhadores, espanhol, no artigo $14^{18}$.

$\mathrm{Na}$ Espanha, o tempo máximo do contrato de experiência é de seis meses para técnicos qualificados, e de dois meses para os demais trabalhadores, sendo este também o tempo máximo de experiência para os domésticos ${ }^{19}$. Neste período de prova deve-se pactuar necessariamente por escrito, ad solemnitatem coforme entendimento prolatado na Sentença do Tribunal Supremo (STS

\footnotetext{
${ }^{17}$ Art. 445, Parágrafo único. O contrato de experiência não poderá exceder de 90 (noventa) dias.

${ }^{18}$ ESPANHA. Real Decreto Legislativo no 01/1995: Artigo 14 período de prova:

1. Podrá concertarse por escrito un período de prueba, con sujeción a los límites de duración que, en su caso, se establezcan en los Convenios Colectivos. En defecto de pacto en Convenio, la duración del período de prueba no podrá exceder de seis meses para los técnicos titulados, ni de dos meses para los demás trabajadores. En las empresas de menos de veinticinco trabajadores el período de prueba no podrá exceder de tres meses para los trabajadores que no sean técnicos titulados. El empresario y el trabajador están, respectivamente, obligados a realizar las experiencias que constituyan el objeto de la prueba.
}

Será nulo el pacto que establezca un período de prueba cuando el trabajador haya ya desempeñado las mismas funciones con anterioridad en la empresa, bajo cualquier modalidad de contratación.

2. Durante el período de prueba, el trabajador tendrá los derechos y obligaciones correspondientes al puesto de trabajo que desempeñe como si fuera de plantilla, excepto los derivados de la resolución de la relación laboral, que podrá producirse a instancia de cualquiera de las partes durante su transcurso.

3. Transcurrido el período de prueba sin que se haya producido el desistimiento, el contrato producirá plenos efectos, computándose el tiempo de los servicios prestados en la antigüedad del trabajador en la empresa.

Las situaciones de incapacidad temporal, maternidad, y adopción o acogimiento, que afecten al trabajador durante el período de prueba, interrumpen el cómputo del mismo siempre que se produzca acuerdo entre ambas partes.

19 Artículo 6. Duración del contrato y periodo de prueba.

1. El contrato podrá celebrarse por tiempo indefinido o por una duración determinada, en los términos previstos en el Estatuto de los Trabajadores y sus normas de desarrollo.

2. Podrá concertarse por escrito un periodo de prueba en los términos del artículo 14 del Estatuto de los Trabajadores. Durante dicho periodo, que no podrá exceder de dos meses, salvo lo previsto en convenio colectivo, el empleador y el empleado de hogar estarán obligados a cumplir con sus respectivas prestaciones, si bien podrá producirse la resolución de la relación laboral por cualquiera de las partes, con el periodo de preaviso ajustado a lo que se pacte, sin exceder, en ningún caso, de siete días naturales. de 2001). A ausência do contrato presume-se que seja por tempo indeterminado e o seu interstício incorpora ao tempo de trabalho e para todos os efeitos remuneratórios e indenizatórios ${ }^{20}$.

No direito brasileiro existe ainda algumas decisões em que não se reconhece a legalidade do contrato de experiência firmado entre as partes. Isto ocorre porque não existe uma lei que confira tal direito ao doméstico e também em razão de que o Contrato de Experiência regulado na CLT não se aplica à aquela classe laboral. Dessa forma, inexistindo o permissivo legal, os contratos firmados com esta característica são tidos por tempo indeterminado.

Cabe destacar que, embora tardia, a iniciativa, porém oportuna, sob o ponto de vista do princípio da dignidade humana, está no Senado Federal para votação que ocorrerá possivelmente ainda em 2012, o Projeto de Lei 5140/09, que permite o contrato de experiência de até 90 dias na relação laboral do empregado doméstico. O projeto já foi aprovado na Câmara Federal e atualmente está aguardando votação final no Senado. Pelo Projeto de Lei, a rescisão que ocorresse sob o manto do contrato de experiência, até o prazo de 90 dias, o empregador não teria a obrigatoriedade de pagar a multa rescisória com base no Fundo de Garantia (FGTS) bem como o relativo ao aviso prévio ${ }^{21}$.

Embora não existindo amparo legal, mas havendo decisões jurisprudenciais para o período de prova, o empregador deverá assinar a carteira de trabalho no máximo 48 (quarenta e oito) horas logo após a admissão, bem como fazer o recolhimento previdenciário.

O contrato de trabalho do doméstico no sistema espanhol e brasileiro não difere quanto à forma ${ }^{22}$ (escrito ou verbal) e duração ${ }^{23}$ (prazo indeterminado e determinado), com ressalva do contrato de experiência aludido no tópico anterior.

No caso do contrato de trabalho do empregado doméstico espanhol, o Real Decreto estabelece que se a

${ }^{20}$ Cf. FIGUEIRAL, Eduardo Ortega. Toda Contratación Laboral. 12. ed. Valência: Ed. CISS, 2008; GOERLICH PESET, José María et al. Contratación laboral y tipos de contrato: criterios jurisprudenciales. Valladolid: Lex Nova, 2010. p. 85 e 86.

${ }^{21}$ BRASIL. Senado Federal. Projeto de Lei 5140/09. Disponível em: <http://www.senado.gov.br/atividade/materia/detalhes. asp?p_cod_mate=101529>. Acesso em: 14 mar. de 2012.

${ }^{22}$ Art. 5.1 do Real Decreto 1620/2011 e Art. 443 da CLT.

${ }^{23}$ Art. 6.1 do Real Decreto 1620/2011 e Art. 443 da CLT. 
prestação de serviço ultrapassar quatro semanas tem-se por prazo indeterminado, da mesma forma que "na ausência de pacto escrito, o contrato de trabalho se presumirá ajustado por tempo indeterminado e a jornada completa quando sua duração seja superior a quatro semanas, salvo prova em contrario que indique a sua natureza temporal ou o caráter parcial dos serviços" ${ }^{24}$.

A regra geral é do contrato de trabalho por tempo indeterminado, tanto no Brasil como na Espanha, como corolário do princípio da continuidade da relação de emprego. Desta forma é considerado indeterminado o contrato em que se pactua sem estabelecer limite de tempo algum na prestação de serviço ${ }^{25}$. É a modalidade contratual padrão e corrente tanto que, se o contratado por tempo determinado ultrapassar prazo estabelecido, intencionalmente ou não, prestando serviço, transformará sua característica para tempo indeterminado ${ }^{26}$.

O contrato de trabalho por tempo determinado é uma das modalidades que regulamentam a relação empregatícia no Brasil ${ }^{27}$. Esta modalidade de contrato está disciplinada nos artigos 443, 451, 479 e 480 da Consolidação das Leis do Trabalho onde se encontra sua definição, regras de aplicação e rescisão.

\subsection{Remuneração}

O Estatuto do Trabalhador ${ }^{28}$ conceitua como salário o total das percepções econômicas do trabalhador, em dinheiro ou salário in natura, pela prestação de serviço laboral por conta de terceiros tendo como valor mínimo o valor estipulado nacionalmente no denominado salário mínimo interprofissional.

O salário mínimo interprofissional é a remuneração mínima que um trabalhador pode perceber numa relação de prestação de trabalho na Espanha. O valor busca

${ }^{24}$ Art. 5.2 do Real Decreto n ${ }^{\circ}$. 1620/2011, Espanha.

${ }^{25}$ FIGUEIRAL, Eduardo Ortega. Toda Contratación Laboral. 12. ed. Valência: CISS, 2008. p.57.

${ }^{26}$ MARTINS, Sergio Pinto. Direito do trabalho. 15. ed. atual. São Paulo: Atlas, 2002. p. 102.

${ }^{27}$ Ibidem, p. 103.

${ }^{28}$ Espanha, Real Decreto Legislativo no 01/1995, Artigo 26. “Do salário. 1. Se considerará salário a totalidade das percepções econômicas dos trabalhadores, em dinheiro ou em espécie, pela prestação profissional dos serviços laborais por conta alheia, à retribuição do trabalho efetivo, qualquer que seja a forma de remuneração, ou os períodos de descanso computados como de trabalho". (tradução nossa) retribuir o trabalhador de forma que consiga manter as necessidades básicas sua e de sua família ${ }^{29}$.

O trabalhador doméstico tem sua remuneração fixada em mês, dia ou hora. Desta forma o salário mínimo interprofissional fixado para 2012 pelo Real Decreto $1.888 / 2011^{30}$ é de $\mathrm{R} \$ 11,42$ por hora trabalhada, $\mathrm{R} \$ 48,67$, por dia ou R\$1.460,04/mês (valor em real segundo a cotação de março/2012).

O salário mínimo no Brasil foi estabelecido para 2012 é de $\mathrm{R} \$ 622,00$ por mês, “o valor diário do salário mínimo corresponderá a $\mathrm{R} \$ 20,73$ e o valor horário a $\mathrm{R} \$$ 2,83 . $^{31 “}$

Em síntese:

\begin{tabular}{l|l|l}
\hline & Espanha & Brasil \\
Salário mínimo: & Salário mínimo: \\
Remuneração & $\mathrm{R} \$ 1.460,04$ & $\mathrm{R} \$ 622,00$ \\
mínima* & Valor diário: & Valor diário: \\
& $\mathrm{R} \$ 48,67$ & $\mathrm{R} \$ 20,73$ \\
& Valor por hora: & Valor por hora: \\
& $\mathrm{R} \$ 11,42$ & $\mathrm{R} \$ 2,83$ \\
\hline
\end{tabular}

${ }^{*}$ Cotação do euro de 01/04/2012

Pinto Martins ${ }^{32}$ diz que:

[...]salário é toda prestação fornecida diretamente ao trabalhador pelo empregador em decorrência do contrato de trabalho, seja em função da contraprestação do trabalho, da disponibilidade do trabalhador, das interrupções contratuais ou demais hipóteses previstas na legislação.

A CLT chama a atenção para a abrangência deste salário mínimo estabelecendo que o seu valor seja idôneo

${ }^{29}$ GIRÓN, Martinez Jesus. Derecho del trabajo. 2. ed. España: Netbiblo, 2006, p. 216.

${ }^{30}$ Espanha, Real Decreto no 1.888 , de 30 de dezembro 2011, Artigo 1. "Quantia do salário mínimo interprofissional. O salário mínimo para qualquer atividade na agricultura, na indústria e nos serviços, sem distinção de sexo nem idade dos trabalhadores, está fixado em 21,38 euros/dia ou 641,40 euros/mês, segundo esteja o salário fixado por dias ou por meses". (tradução nossa)

${ }^{31}$ Decreto $n^{\circ} 7.655$, de 23 de dezembro de 2011. Este decreto regulamenta a Lei no 12.382, de 25 de fevereiro de 2011, que dispõe sobre o valor do salário mínimo e a sua política de valorização de longo prazo.

${ }^{32}$ MARTINS, Sergio Pinto. Comentários à CLT. 14. ed. São Paulo: Atlas, 2010. p.159. 
para, por dia normal de serviço ser “[...] capaz de satisfazer, em determinada época e região do país, as suas necessidades normais de alimentação, habitação, vestuário, higiene e transporte" ${ }^{33}$. Esta definição é a mesma descrita por Plácido e Silva ${ }^{34}$

De acordo com Monteiro ${ }^{35}$, a Natureza Jurídica do Salário é:

a) O salário como preço do trabalho, esse posicionamento, típico do liberalismo econômico, vigorava no tempo em que se equiparava o trabalho a uma mercadoria, não se justificando nos dias atuais; b) O salário é uma indenização, para ao empregado como compensação pelas energias por ele despendidas em virtude de uma relação contratual de trabalho; c) Natureza alimentícia do salário, a principal crítica a essa corrente reside no fato de que o salário não tem caráter alimentar apenas, pois possui outros fins, como os de propiciar ao empregado habitação, higiene, transporte, educação, assegurando a manutenção do empregado e de sua família; d) Contraprestação pelo serviço prestado; e) dever de retribuição.

Observa-se que, no que pese o Brasil ter conquistado a $6^{\mathrm{a}}$ posição no ranking das maiores economia do mundo ${ }^{36}$, o custo de vida do Brasil e Espanha não diferenciam muito. Segundo a consultora econômica MERCER ${ }^{37}$ na pesquisa que envolveu 214 cidades em cinco continentes e que mede o custo comparativo de mais de 200 itens em cada local, dentre eles moradia, transporte, alimentação, vestuário, utilidades domésticas e entretenimento, respectivamente, São Paulo (10 lugar) e Rio de Janeiro (12 lugar) foram em 2011 os locais mais caros, e Madri/

${ }^{33}$ Art. 76 da CLT.

34 "Salário mínimo é a contraprestação mínima devida e paga diretamente pelo empregador a todo trabalhador, inclusive ao trabalhador rural, sem distinção de sexo, por dia normal de serviço, e capaz de satisfazer as suas necessidades normal de alimentação, habitação, vestuário, higiene e transporte. Praticamente, pois, o salário mínimo correspondente a matéria de um QUANTUN mínimo, indispensável a mantença do empregado em um dia, nele se incluindo, não somente o dinheiro necessário à alimentação."

${ }^{35}$ BARROS, Alice Monteiro de. Curso de direito do trabalho. 2. ed. São Paulo: LTR, 2002. p. 237.

${ }^{36}$ JORNAL O ESTADO DE MINAS. Disponível em: < http:// www.em.com.br /app/noticia/economia/2011/12/26/internas_economia,269281/brasil-supera-reino-unido-e-agora-esexta-economia-do-mundo.shtml $>$.

${ }^{37}$ Merce é uma consultoria Marsh \& McLennan Companies, Inc. Disponível em: $<\mathrm{http}: / /$ www.mercer.com.br/press-releases/1420580>. Acesso em: 1 de fev. 2012.
ESP ficou em $60^{\circ}$ lugar ${ }^{38}$, ou seja morar em São Paulo ou Rio de Janeiro é mais caro que morar em Madri.

\subsection{Férias do empregado doméstico}

O conceito de férias no direito brasileiro e espanhol são semelhantes podendo-se valer do ensino de Pinto Martins ${ }^{39}$, de que férias advém do latim "dias feriales", a saber:

O período do contrato de trabalho, em que o empregado não presta serviço, mas aufere remuneração do empregador, após ter adquirido o direito no decurso de 12 meses. As férias visam, portanto, a restauração do organismo após um período em que foram desprendidas energias no trabalho. Importam direito ao lazer, ao descanso, ao ócio.

Na regra geral, o art. 38.1 do Estatuto dos Trabalhadores (ET), trata das "férias anuais retribuídas", de gozo obrigatório ("não substituível por compensação econômica" dobrada) e cuja duração "em nenhum caso... será inferior a trinta dias naturais. O período de gozo da mesma - que não tem porque ser necessariamente ininterrupta e contínua, pois o artigo 38.2 do ET fala de "período de seu gozo"- deve aparecer fixado para todo os trabalhadores no calendário correspondente da empresa, tendo o trabalhador direito de conhecer "as datas que lhes correspondam dois meses antes, ao menos, do começo do gozo", comenta Girón ${ }^{40}$.

As férias do empregado doméstico espanhol ${ }^{41}$ é de trinta dias por ano de serviço, podendo fracionar esse período em períodos menores desde que, ao menos, quinze dias deverão ser consecutivos, salvo empregos à tempo

${ }^{38}$ MERCER. Consulting outsourcing investiments. Disponível em: <http://www.mercer.com/press-releases/1420615>. Acesso em: 3 fev. 2012.

${ }^{39}$ MARTINS, Sergio Pinto. Comentários à CLT. 14. ed. São Paulo: Atlas, 2010. p. 193.

${ }^{40}$ GIRÓN, Martinez Jesus. Derecho del trabajo. 2. ed. España: Netbiblo, 2006, p. 207.

${ }^{41}$ Art. 9.7 "O período de férias anuais será de trinta dias naturais, que poderá se fracionar em dois ou mais períodos, porém, ao menos um deles será no mínimo de quinze dias naturais consecutivos. O período ou períodos de gozo das férias será acordado entre as partes. Na ausência do referido acordo, quinze dias poderá fixar o empregador, de acordo com as necessidades familiares e tempo restante escolherá o empregado livremente. Neste este caso, as datas das férias deverão ser conhecidas com dois meses de antecedência da data do início de seu gozo. Durante o período ou períodos de férias, o empregado doméstico não estará obrigado a residir no domicílio familiar ou no lugar aonde se desloque a família ou alguns de seus membros". (tradução nossa) 
parcial. O doméstico interno - aquele que reside na residência familiar - tem o direito de durante o período de férias não estar obrigado a continuar na residência ou no local onde presta seus serviços. Contudo, se continuar na casa deverá seguir os costumes da família, sem obrigatoriedade de assumir suas atividades laborais.

Quanto à fixação da data faz férias estabelece no art. 9.7 do Real Decreto que as partes poderão escolher as datas das férias e fixa-las no contrato. Em caso de não haver acordo, o empregador marcará a seu critério e conveniência os primeiros quinze dias e o empregado agendará os outros quinze, conforme seu querer.

O empregado doméstico brasileiro tem direito às férias anuais remuneradas de 30 dias com o respectivo acréscimo constitucional de $1 / 3$ ao salário normal, após o período aquisitivo que são de 12 meses de trabalho, prestado ao mesmo empregador ${ }^{42}$, conforme entendimento pacífico do TST:

De fato, não há dúvidas que os artigos da Consolidação das Leis do Trabalho, no tocante às férias, aplicam-se integralmente a esta categoria de empregados. Com efeito, os empregados domésticos são regidos por lei própria, qual seja, a Lei 5.859/72, e pelas regras previstas na Constituição da República. Contudo, já em 1973, a lei em referência foi regulamentada pelo Decreto n. ${ }^{\circ} 71.885$, que previu em seu artigo $2^{\circ}$ : Art. $2^{\circ}$ Excetuando o Capítulo referente a férias, não se aplicam aos empregados domésticos as demais disposições da Consolidação das Leis do Trabalho ${ }^{43}$.

Quanto à fixação da data das férias, diferentemente da regra espanhola, será estabelecida por ato do empregador, "nos 12 (doze) meses subsequentes à data em que o empregado tiver adquirido o direito" 44 .

\footnotetext{
${ }^{42}$ A Lei $5.859 / 1972$ estabelecia que o empregado doméstico tinha direito a 20 dias de férias, contudo a Lei 11.324/2006 alterou esse direito ajustando ao preceito constitucional de 30 dias acrescido de $1 / 3$ a mais de salário.

${ }^{43}$ BRASIL. Superior Tribunal do Trabalho. RR - 10040063.2009.5.09.0670 da $1^{\text {a }}$ Turma. Brasília, 07 de março de 2012. Disponível em: <http://aplicacao5.tst.jus.br/consultaunificada2/inteiroTeor.do?action=printInteiroTeor\&form at $=$ html \&highlight $=$ true \&numeroFormatado $=\mathrm{RR} \% 20-\% 20$ 100400-63.2009.5.09.0670\&base $=$ acordao \& rowid $=$ AAANG hABIAAADhPAAO\&dataPublicacao $=16 / 03 / 2012 \&$ query $=\mathrm{F}$ $\%$ E9rias $\% 20 \% 20 \mathrm{e} \% 20$ empregado $\% 20$ dom $\%$ E9stico $>$.Acesso em: 18 de mar. 2012.

${ }^{44}$ Artigo 134 da CLT.
}

\subsection{Jornada de trabalho e compensação:}

Conforme Carrion ${ }^{45}$ e, jornada de trabalho é o tempo empregado no labor diário do empregado com habitualidade, excluídas as horas extraordinárias. Na mesma linha é conceito de Sergio Pinto Martins que ressalta que este tempo de trabalho deve ser visto sob três aspectos:

Do tempo efetivamente trabalhado;

Do tempo à disposição do empregador; e

Do tempo in itinere.

No Brasil, foi a Constituição Federal de 1988 que estabeleceu a "duração do trabalho normal não superior a oito horas diárias e quarenta e quatro semanais, facultada a compensação de horários e a redução da jornada, mediante acordo ou convenção coletiva de trabalho" ${ }^{46}$. Entretanto, como a Constituição não conferiu ao empregado doméstico direito à jornada de oito horas diárias e quarenta e quatro semanais, razão pela qual, não tem direito à verba compensatória da intrajornada e às horas extraordinárias.

A Legislação espanhola harmonizada com a diretiva europeia de 2002 que dispõem sobre a organização do tempo de trabalho na União Europeia ${ }^{47}$, os trabalhadores não podem ser obrigados a trabalhar mais de quarenta horas por semana, estando assim regulado no art. 34 do Estatuto dos Trabalhadores ${ }^{48}$.

Nos dois países a classificação da jornada de trabalho se dá de forma semelhante:

1) Quanto à duração: considera-se ordinária ou normal a jornada que se desenvolve dentro do limite legal, e extraordinária ou suplementar, aquela que ultrapassa o limite legal estabelecido; Considera-se contínua quando o labor ocorre sem intervalos, e descontínua, se ocorrer intervalo ${ }^{49}$;

\footnotetext{
${ }^{45}$ CARRION, Valentin. Comentários à Consolidação das leis do trabalho. 35. ed. São Paulo: RT, 2010.

${ }^{46}$ BRASIL. Constituição da República Federativa do Brasil (1988). art. $7^{\circ}$, XIII.

${ }^{47}$ WORKING TIME DIRECTIVE. 32003L0088 - 4/11/2002. Disponível em:<http://eur-lex.europa. eu/LexUriServ /LexUriServ.do ?uri=CELEX: 32003 L 0088:EN:HTML>. Acesso em: 23 jan. 2012.

${ }^{48}$ GIRÓN, Martinez Jesus. Derecho del trabajo. 2. ed. España: Netbiblo, 2006, p. 82.

${ }^{49}$ GOERLICH PESET. Contratación laboral y tipos de contrato: criterios jurisprudenciales. Valladolid: Lex Nova, 2010, p. 273- 274; FIGUEIRAL, Toda Contratación Laboral. 12. ed. Valência: CISS, 2008, p. 57.
} 
2) Quanto ao período, pode ser diurno entre 5 e 22 horas e noturno entre 22 horas e às 5 , do dia seguinte. Na Espanha considera-se diurno o intervalo entre 6 e 22 horas e noturno das 22 às 06 horas. Todavia são iguais os períodos do labor, podendo ser mista quando o labor desenvolve tanto no período diurno como noturno, ou ainda, em revezamento, modalidade em que há labor alternado entre dia e noite, semanal ou quinzenalmente ${ }^{50}$.

Importante ressaltar que no Brasil os empregados domésticos não têm direito ao recebimento do adicional noturno nem o reconhecimento da hora noturna reduzida, por ausência de previsão legal.

\subsection{Horário intrajornada}

Os descansos previstos na intrajornada são aqueles concedidos ao trabalhador dentro de uma mesma jornada de trabalho. Esse direito objetiva o repouso e alimentação do trabalhador, com vistas à sua recomposição física e a manutenção da sua plena capacidade de trabalho. Este direito existe de forma geral a todos os trabalhadores espanhóis, porém no Brasil não existe para os empregados domésticos.

O empregado doméstico espanhol tem direito, pelo menos a duas horas por dia para as suas refeições, tempo que não se computará o trabalho ${ }^{51}$. No caso empregado brasileiro, como dito acima, não tem este direito regulado, logo não tem o direito nem a possibilidade da respectiva indenização.

\subsection{Descanso semanal remunerado.}

O descanso semanal remunerado caracteriza-se pela interrupção remunerada da prestação de serviço, na qual o empregado não está obrigado a laborar para seu empregador pelo período que a legislação estabelece.

\footnotetext{
${ }^{50}$ Artigo 9.2 Respeitando os máximos de trabalho e períodos mínimos de descanso, tempo de duração e presença do doméstico será objeto de remuneração ou compensação nos mesmos termos, conforme acordado pelas partes. Em qualquer modo, salvo que se acordem a compensação com períodos equivalentes de descanso pago, as horas de presença não poderão exceder a 20 horas semanais em média em um período de um mês de referencia e será remunerado com um salário de pelo menos o valor correspondente às horas normais". (tradução nossa)

${ }^{51}$ Artigo 9.4 O empregado doméstico interno disporá, ao menos, de duas horas diárias para as principais refeições, e este tempo não se computará como de trabalho. (tradução nossa)
}

A limitação da duração da jornada de trabalho existe para garantir ao trabalhador os momentos de restauração de suas funções físicas e psíquicas. $\mathrm{O}$ descanso ou de tempo livre encontra fundamento na ciência médica (aspectos físicos, psicológicos e sanitários), aspectos sociais (vida social, familiar, ócio). Para o empregador é imposto uma penalidade pecuniário como forma de desestímulo à excessiva jornada de trabalho ${ }^{52}$.

Pelo Real Decreto, os domésticos têm direito a trinta e seis horas consecutivas de descanso semanal remunerado, a saber, de sábado à tarde ou segunda de manhã e de todo a domingo. Para aqueles que trabalham por horas, o período de descanso é reduzida na proporção das horas efetivamente trabalhadas. Tal disposição está em consonância com a doutrina laboral espanhola, que conserva o descanso semanal unicamente o caráter retributivo do reposo semanal. Isto se deve, segundo Ahumad "a que o salário do descanso semanal se considera como exigência necessária e essencial para o desfrute efetivo do descanso; a saber, como "um requisito inerente à noção de descanso" ${ }^{53}$.

O descanso semanal remunerado, por sua natureza jurídica é um direito de ordem pública, irrenunciável possui caráter de tutelar, ante a desigualdade de barganha das partes, nos ordenamentos jurídicos do Brasil quanto da Espanha.

\subsection{Menores de 18 anos}

No parágrafo 8, e alíneas de "a" a "d" do Real Decreto $^{54}$ permitiu o trabalho dos menores de idade (15 a 17 anos) no serviço doméstico, estabelecendo a aplicação das mesmas normas contidas no Estatuto dos Trabalhadores aos trabalhadores domésticos menores de idade, a saber:

- Os menores de 18 anos só poderão trabalhar o número máximo de 8 horas

\footnotetext{
${ }^{52}$ MARTINS, Sergio Pinto. Direito do trabalho. 15. ed. atual. São Paulo: Atlas, 2002, p. 454

${ }^{53}$ AHUMAD, José Eduardo López. Orígenes y formación del derecho al descanso semanal: estudios doctrinales. Madrid: Universidad de Alcal, 2002. p. 30. Disponível em: $<$ http:// www2.uah.es/adtss/files/estudios_doctrinales /origenes y formaciondelderechoaldescansosemanal.pdf $>$. Acesso em: 2 fev. 2012. Também comenta GIRÓN, Martinez Jesus. Derecho del trabajo. 2. ed. España: Netbiblo, 2006, p. 70.

${ }^{54}$ ESPANHA. Decreto Real n ${ }^{\circ}$ 1.620/2011. Mimeo. Art. 9.8, a, b, c, d.
} 
diárias ${ }^{55}$ sendo proibida a sua ativação em horas extraordinárias;

- O descanso intrajornada deve ser de no mínimo trinta minutos a cada quatro horas e meia de trabalho;

- É obrigatório o descanso semanal remunerado ${ }^{56}$ de dois dias ininterruptos (sábado e domingo), não se podendo acumular nem trasladar o sábado para outro dia;

- A proibição de trabalho noturno, entendendo-se este, como o período compreendido entre as vinte e duas às seis horas da manhã.

Diferentemente da legislação espanhola, na brasileira é proibido o trabalho de menor de 18 anos como empregado doméstico desde a publicação do Decreto № 6.481, de 12 de junho de 2008. Este Decreto regulamentou os artigos $3^{\circ}$, alínea “d”, e $4^{\circ}$ da Convenção 182 da Organização Internacional do Trabalho (OIT) que trata da proibição das piores formas de trabalho infantil ${ }^{57}$. Nela estão transcritos os prováveis riscos ocupacionais a que o menor, como empregado doméstico, estaria exposto, indicando: “os esforços físicos intensos; isolamento; abuso físico, psicológico e sexual; longas jornadas de trabalho; trabalho noturno; calor; exposição ao fogo, posições antiergonômicas e movimentos repetitivos; tracionamento da coluna vertebral; sobrecarga muscular e queda de nível".

No que pese o Decreto espanhol regulador dos trabalhadores domésticos esteja em descompasso com a orientação da OIT, cabe ressaltar que a Diretiva Europeia é pior todavia, pois permite o trabalho a partir dos

${ }^{55}$ ESPANHA. Estatuto dos Trabalhadores. Real Decreto Legislativo no 01/1995. Mimeo. Art. 34.3.

${ }^{56}$ Ibidem. Art. 37,.1.

${ }^{57}$ BRASIL. Palácio do Planalto. Decreto n. 6481. Disponível em: $<$ http://www.planalto.gov.br/ccivil_03/_ato2007-2010/2008/ decreto/d6481.htm>. Acesso em: 23 jan. 2012.

${ }^{58}$ UNIÃO EUROPÉIA. Proteção dos jovens no trabalho. Disponível em:< http://eur-lex.europa.eu/LexUriServ/LexUriServ.do?uri=CELEX:31994L0033:pt:HTML Acesso em: 2 fev. 2012.

${ }^{59}$ GIRÓN, Martinez Jesus. Derecho del trabajo. 2. ed. España: Netbiblo, 2006, p. 67.

\section{Cessação do vínculo laboral}

Conforme a nova regra hispânica a cessação do contrato seguirá as hipóteses de extinção do contrato prevista no Estatuto do Trabalhador, quais sejam: a) Por mútuo acordo das partes; b) Pelas causas consignadas validamente no contrato; c) Por expiração do tempo contrato. d) Por demissão do trabalhador; e) Por morte, invalidez permanente total ou absoluta do trabalhador; f) Por jubilação do trabalhador. g) Por morte, aposentadoria ou incapacidade do empregador-empresário; h) Por vontade do trabalhador, fundamentada na falta contratual do empregador-empresário; i) Por demissão do trabalhador; e , j) Por decisão da trabalhadora que se veja obrigada a abandonar definitivamente seu trabalho por ser vítima de violência de gênero ${ }^{60}$.

As motivações de rescisão contratual estabelecida pelo Real Decreto ressaltam algumas modalidades previstas no Estatuto dos Trabalhadores, a saber:

a- Demissão disciplinar do doméstico ${ }^{61}$ : Neste caso o trabalhador se deverá ser notificado por escrito, manifestando as razões previstas no Estatuto dos Trabalhadores. Não obstante esta notificação, se a justiça declare improcedente a demissão o doméstico fará jus às indenizações que deve ser paga integralmente em espécie. O valor da indenização calcula-se dividindo o salário mensal por vinte dias. Deste resultado multiplica-se pelo numero de anos de trabalho, limitado ao máximo de 12 anos.

b- Demissão por falta do empregador: Neste caso aplica-se a indenização descrita no tópico anterior (a);

c- Demissão por abandono do empregador: Neste caso o empregador deve notificar por escrito ao empregado de forma clara e inequívoca a sua vontade de rescindir o contrato emprego por justa causa.

d- Rescisão por desistimiento (equivalente à rescisão sem justa causa no Brasil).

\footnotetext{
${ }^{60}$ Artigo 49.1, alíneas de “a” à “m”. Estatuto do Trabalhador, Espanha.

${ }^{61}$ ESPANHA. Real Decreto no 1.620/2011. Mimeo. Art. 11.2
} 
Por desistimiento entende-se a simples vontade do empregador em rescindir o contrato. Neste caso o empregador deverá comunicar por escrito a rescisão do contrato. O empregador deverá em um ato notificar (aviso prévio) e indenizar o doméstico. A indenização "é equivalente à sete dias naturais de salário em espécie multiplicado pelo numero de anos ano naturais de duração do contrato, incluído o período de pré-aviso, com o limite de seis mensalidades" ${ }^{62}$. Se o empregador preterir alguma formalidade desta modalidade, a indenização passa de sete para vinte dias de salários que será multiplicado pelo número de anos naturais do contrato, cujo limite passa de seis para doze mensalidades.

Na legislação brasileira o doméstico poderá ter rescindido o contrato em três principais hipóteses ${ }^{63}$ :

a) A pedido do doméstico. Neste caso de rescisão, o empregado doméstico deverá notificar o empregador mediante o aviso prévio. Nesta hipótese deverá trabalhar o mês após notificação ou acordar com o empregador o desconto de um salário de sua remuneração. Terá direito: ao saldo de salários dos dias que o empregado trabalhou e não recebeu; ao $13^{\circ}$ proporcional aos meses que trabalhou; e às férias proporcionais aos meses que efetivamente trabalhou.

b) Demissão arbitrária ou sem justa causa. Nesta hipótese o empregado doméstico terá rescindido o contrato por simples decisão ou iniciativa do empregador. Decorrem os seguintes direitos: aviso prévio; saldo de salários dos dias trabalhados e não recebidos; $13^{\circ}$ proporcional aos meses trabalhados; férias proporcionais aos meses trabalhados acrescido do terço

${ }^{62}$ GIRÓN, Martinez Jesus. Derecho del trabajo. 2. ed. España: Netbiblo, 2006, p. 83.

${ }^{63}$ MARTINS, Sergio Pinto. Direito do trabalho. 15. ed. atual. São Paulo: Atlas, 2002, p. 313, 314. constitucional e saque do Fundo de Garantia, isto se o empregador tiver optado na relação laboral pelo depósito.

c) Demissão por justa causa. Neste tipo de demissão as causas são as previstas na CLT que sintetizamos topicamente: a) ato de improbidade; incontinência de conduta ou mau procedimento; condenação criminal do empregado, transitada em julgado; desídia no desempenho das respectivas funções; embriaguez habitual ou em serviço; ato de indisciplina ou de insubordinação; abandono de emprego; ato lesivo da honra ou da boa fama praticado no serviço contra qualquer pessoa, ou ofensas físicas, nas mesmas condições, salvo em caso de legítima defesa, própria ou de outrem; ato lesivo da honra ou da boa fama ou ofensas físicas praticadas contra o empregador e superiores hierárquicos, salvo em caso de legítima defesa, própria ou de outrem; prática constante de jogos de azar. O doméstico, assim, terá o seguinte direito: saldo de salários dos dias que tiver trabalhado e não recebido.

Cabe ressaltar que a empregada doméstica gestante está protegida de despedida arbitrária ou sem justa causa $^{64}$, mas não da demissão por justa causa ou a pedido da própria empregada ${ }^{65}$.

${ }^{64}$ Como pode ser visto da decisão do Egrégio TRT 04a Região: Ementa: ESTABILIDADE DA GESTANTE - JUSTA CAUSA - Autora grávida no momento da despedida. Prova dos autos que demonstra a configuração da hipótese prevista na alínea e do art. 482 da CLT (desídia). Justa causa caracterizada. Indenização pela estabilidade provisória da gestante indevida. (TRT 04 ${ }^{\mathrm{a}}$ R. - RO 0021000-62.2009.5.04.0662 - 6a T. - Rel ${ }^{\mathrm{a}}$ Maria Inês Cunha Dornelles - DJe 18.05.2010)

${ }^{65}$ Decisão do Egrégio TRT 04 ${ }^{\mathrm{a}}$ Região: ESTABILIDADE PROVISÓRIA DA GESTANTE X JUSTA CAUSA - DESÍDIA - A estabilidade provisória da gestante, prevista no art. 10, II, "b" do $\mathrm{ADCT} / \mathrm{CF}$, não impede a rescisão motivada do contrato de trabalho, fundamentada no art. 482, letra 'e', da CLT. A reiteração de faltas injustificadas ao serviço caracteriza a desídia do empregado no desempenho de suas funções, mormente, quando, em que pese advertido e suspenso, persistiu o empregado no cometimento das faltas. (TRT 05a R. - RO 017270084.2009.5.05.0621 - 4a T. - Rel ${ }^{\mathrm{a}}$ Nélia Neves - DJe 29.04.2010 


\section{Aviso prévio}

No direito espanhol, o empregado doméstico tem direito ao aviso prévio de vinte dias se somar mais de um ano de trabalho e de sete dias se for inferior a um ano. Durante o período de aviso prévio, o empregado de jornada completa terá direito, sem prejuízo de sua remuneração, a uma licença de seis horas semanais para buscar novo emprego ou o empregador poderá substituir o tempo do aviso por uma indenização equivalente a essas horas, estando pois dispensado o empregado de cumprir o prazo.

O Aviso prévio proveniente de demissão ou rescisão do doméstico que pernoita na residência do empregador, não deve ser feito entre as dezessete e oito horas, a não ser que a rescisão do contrato seja motivada por uma violação muito grave dos deveres de lealdade e confiança.

Em qualquer caso, cabe destacar que simultaneamente à comunicação da rescisão, o empregador deverá por a disposição do trabalhador uma indenização, que se pagará integramente em espécie, na quantia equivalente ao salário correspondente a doze dias naturais por ano de trabalho, não excedendo de seis mensalidades ${ }^{66}$.

O empregado doméstico brasileiro também tem o direito de receber e dar o aviso prévio, lembrando-se que o aviso prévio é uma obrigação, das partes que pretende rescindir o contrato, de informar a outra, com no mínimo trinta dias de antecedência, quando do seu exercício, e a sua inobservância geram direitos e obrigações à parte que descumprir esta regra. O tempo relativo ao aviso prévio refletirá sobre as verbas das férias e $13^{\circ}$ salário.

O empregador que não der o aviso prévio deverá indenizar o doméstico valor equivalente a um salário

${ }^{66}$ Decisão do Egrégio TRT 04ª Região: ESTABILIDADE PROVISÓRIA DA GESTANTE X JUSTA CAUSA - DESÍDIA - A estabilidade provisória da gestante, prevista no art. 10, II, "b" do ADCT/CF, não impede a rescisão motivada do contrato de trabalho, fundamentada no art. 482, letra 'e', da CLT. A reiteração de faltas injustificadas ao serviço caracteriza a desídia do empregado no desempenho de suas funções, mormente, quando, em que pese advertido e suspenso, persistiu o empregado no cometimento das faltas. (TRT 05 ${ }^{\mathrm{a}}$ R. - RO 017270084.2009.5.05.0621 - 4 ${ }^{\mathrm{a}}$ T. - Rela Nélia Neves - DJe 29.04.2010. Art. $11,3, \S 2^{\circ}$.
Quadro 2: Comparativo sintético dos direitos dos empregados domésticos espanhóis e brasileiros.

\begin{tabular}{|c|c|c|}
\hline DIREITOS & $\begin{array}{c}\text { Doméstico } \\
\text { Espanhol }\end{array}$ & $\begin{array}{l}\text { Doméstico } \\
\text { Brasileiro: }\end{array}$ \\
\hline Vinculo jurídico & Contrato & $\begin{array}{l}\text { Carteira de Trabalho } \\
\text { assinada (inclusive } \\
\text { no contrato de } \\
\text { experiência). }\end{array}$ \\
\hline $\begin{array}{l}\text { Jornada } \\
\text { trabalho }\end{array}$ & Máximo: 40 horas & Não há controle \\
\hline $\begin{array}{l}\text { Contrato de } \\
\text { experiência }\end{array}$ & $\begin{array}{l}\text { Sim: até quatro } \\
\text { semanas }\end{array}$ & Sim até 90 dias \\
\hline $\begin{array}{l}\text { Informação } \\
\text { detalhada da } \\
\text { prestação de } \\
\text { serviço }\end{array}$ & Obrigatória & Não obrigatória \\
\hline Menor de idade & $\begin{array}{l}\text { Permitido (16 e } 17 \\
\text { anos) }\end{array}$ & Proibido \\
\hline $\begin{array}{l}\text { Remuneração } \\
\text { mínima }\end{array}$ & $\begin{array}{l}\text { Salário mínimo: } \mathrm{R} \$ \\
1.460,04 \\
\text { Valor diário: } \mathrm{R} \$ \\
48,67 \\
\text { Valor por hora: } \mathrm{R} \$ \\
11,42\end{array}$ & $\begin{array}{l}\text { Salário mínimo: } \mathrm{R} \$ \\
622,00 \\
\text { Valor diário: } \mathrm{R} \$ \\
20,73 \\
\text { Valor por hora: } \mathrm{R} \$ \\
2,83\end{array}$ \\
\hline $\begin{array}{l}\text { Gratificações } \\
\text { extraordinárias }\end{array}$ & \begin{tabular}{|l|}
$13^{\circ}$ e $14^{\circ}$ salário \\
(pago a cada 6 \\
meses)
\end{tabular} & $13^{\circ}$ salário \\
\hline Horas extras & Sim & Não tem direito \\
\hline $\begin{array}{l}\text { Limite de } \\
\text { jornada de } \\
\text { trabalho }\end{array}$ & Sim & Não tem direito \\
\hline $\begin{array}{l}\text { Repouso } \\
\text { semanal } \\
\text { remunerado }\end{array}$ & Sim & Sim \\
\hline $\begin{array}{l}\text { Feriados civis e } \\
\text { religiosos }\end{array}$ & $\begin{array}{l}\text { Sim (máximo: } 14 \\
\text { feriados) }\end{array}$ & Sim \\
\hline Férias & Sim, 30 dias & Sim, 30 dias \\
\hline $\begin{array}{l}\text { Licença- } \\
\text { maternidade }\end{array}$ & Sim & Sim \\
\hline $\begin{array}{l}\text { Vale- } \\
\text { transporte. }\end{array}$ & Sim & Sim \\
\hline $\begin{array}{l}\text { Verbas } \\
\text { rescisórias }\end{array}$ & Sim & Sim \\
\hline Aviso Prévio & $\begin{array}{l}\text { Sim: } 20 \text { dias (mais } \\
\text { de ano trabalho) } \\
7 \text { dias (menos de } \\
\text { ano trabalho) }\end{array}$ & $\begin{array}{l}\text { Sim, } 30 \text { dias (não } \\
\text { pacífica). }\end{array}$ \\
\hline FGTS & $\begin{array}{l}\text { Inexiste } \\
\text { congênere }\end{array}$ & $\begin{array}{l}\text { Sim, se o } \\
\text { empregador optar. }\end{array}$ \\
\hline $\begin{array}{l}\text { Seguro- } \\
\text { desemprego. }\end{array}$ & Não & $\begin{array}{l}\text { Sim (se tiver } \\
\text { mínimo de } 15 \\
\text { depósitos de FGTS) }\end{array}$ \\
\hline Saúde pública & Sim & Sim \\
\hline Maternidade & $\begin{array}{l}16 \text { semanas }+2 \\
\text { semanas por filho, } \\
\text { se gêmeos. }\end{array}$ & 120 dias \\
\hline $\begin{array}{l}\text { Salário- } \\
\text { maternidade }\end{array}$ & Não & Sim \\
\hline Auxílio doença & Sim & Sim \\
\hline Aposentadoria & Sim, 65 anos & Sim \\
\hline
\end{tabular}




\begin{tabular}{|l|l|l|}
\hline \multicolumn{1}{|c|}{ DIREITOS } & \multicolumn{1}{|c|}{$\begin{array}{c}\text { Doméstico } \\
\text { Espanhol }\end{array}$} & \multicolumn{1}{c|}{$\begin{array}{c}\text { Doméstico } \\
\text { Brasileiro: }\end{array}$} \\
\hline Falecimento & Sim & Sim \\
\hline $\begin{array}{l}\text { Auxílio- } \\
\text { Acidente. }\end{array}$ & Sim & Sim \\
\hline $\begin{array}{l}\text { Dignidade } \\
\text { humana }\end{array}$ & $\begin{array}{l}\text { Protegida: } \\
\text { Principio da não } \\
\text { discriminação }\end{array}$ & $\begin{array}{l}\text { Protegida: } \\
\text { Principio da não } \\
\text { discriminação }\end{array}$ \\
\hline
\end{tabular}

\section{Conclusão}

A guisa de conclusão pede-se dizer que internamente a nova regra espanhola avançou positivamente nos direitos e garantias dos seus trabalhadores domésticos quando, pela atual regra, o trabalhador passou ter o direito de exigir do empregador o contrato de trabalho, e ainda assim, que especifique as condições de trabalho com possibilidade de controle do horário de trabalho para efeito do computo das horas extraordinárias.

Em junho do ano passado os delegados da Organização Internacional do Trabalho (OIT) aprovaram normas internacionais para melhorar as condições de trabalho dos empregados domésticos de todas as nações. Assim, o Projeto de Lei 262/2011, de autoria do Dep. Marçal Filho - PMDB/MS busca regular a duração do trabalho do empregado doméstico em oito horas diárias e quarenta e quatro semanais, bem como o estabelecimento da remuneração pelos serviços extraordinários e trabalho noturno.

Com a nova regulação espanhola os momentos de descansos relativo a intrajornada, entre jornadas e descanso semanal remunerado ficaram devidamente estabelecidos. E, com a precisão da regra assinala a certeza das formas de compensação do trabalhador doméstico e dos instrumentos para reivindicar seus direitos para receber a justa retribuição pelas horas laboradas.

Salta aos olhos a brutal diferença o valor do salário mínimo pago a um trabalhador doméstico espanhol e o pago ao brasileiro. É certo que existem diferenças estruturais entre as duas realidades, porém o Brasil figura como a sexta economia mundial e como tal têm que reestruturar o tecido os princípios e prioridades que organizam sociedade econômica. As cidades brasileiras como São Paulo, Rio de Janeiro, Recife, Porto Alegre, figuram nas pesquisas com custo de vida compatível as das maiores que de Madri, Nova York e Londres, porém não com a mesma com qualidade de vida ao cidadão-trabalhador.
Cabe destacar que o Projeto de Lei 5140/09, aprovado da Câmara e que certamente será aprovado pelo Senado, permitirá o contrato de experiência de até 90 dias na relação laboral do empregado doméstico, sanando assim, as controvérsias relativas a este direito.

Há muito a percorrer no reconhecimento dos direitos e nos ajustes das variantes econômicas e políticas que conjugarão forças e esforços com todos os atores sociais para o estabelecimento de melhores condições de trabalho aos empregados domésticos, instrumentalizando, assim, o principio da dignidade humana.

\section{Referências}

AHUMAD, José Eduardo López. Orígenes y formación del derecho al descanso semana: estudios doctrinales. Madrid: Universidad de Alcal, 2002. Disponível em: $<$ http://www2.uah.es/adtss/files/ estudios_doctrinales / orig enesyformaciondelderechoaldescansosemanal.pdf>. Acesso em: 2 fev. 2012.

BARROS, Alice Monteiro de. Curso de direito do trabalho. 2. ed.São Paulo: LTR, 2002.

BRASIL. Lei n. ${ }^{\circ} 11.324$, de 19 de julho de 2006. Disponível em:<http://www.planalto.gov.br/ccivil_03/_ato20042006/ 2006/ lei/ 1113 24. htm>. Acesso em: 19 fev. 2012.

BRASIL. Decreto n. 6481 Disponível em: <http://www. planalto. gov.br/ccivil_03/_ato2007-2010/2008/decreto/ d6481.htm>. Acesso em: 23 jan. 2012.

BRASIL. Consolidação das leis do trabalho (1843). Disponível em:< http://www.planalto.gov.br/ccivil_03/ decreto-lei/Del5452.htm>. Acesso em: 19 fev. 2012. Acesso em: 19 fev. 2012.

BRASIL. Senado Federal. Projeto de Lei 5140/09. Disponível em: <http://www.senado.gov.br/atividade/ materia/detalhes.asp?p_cod_mate $=101529>$. Acesso em: 14 mar. 2012.

BRASIL. Tribunal Superior do Trabalho. Processo n. RR100400-63.2009.5.09.0670. 2012. Disponível em: <http:// aplicacao 5.tst. jus. br/consultaunificada2/inteiroTeor.do ?action $=$ printInteiroTeor\&format $=$ html\&highlight $=$ true \&numeroFormatado=RR\%20-\%20100400-63.2009 .5. 09 $.0670 \&$ base $=$ acordao\&rowid $=$ AAANGhABIAAADhPA AO\&dataPublicacao $=16 / 03 / 2012 \&$ query $=F \% E 9$ rias $\% 20$ \%20e\%20empregado\%20dom\%E9stico>. Acesso em: 18 mar. 2012.

CARRION, Valentin. Comentários à Consolidação das leis do Trabalho. 35. ed. São Paulo: RT, 2010. 
ESPANHA. Real Decreto Legislativo no 1 de 24 de março 1995. Mimeo.

ESPANHA. Real Decreto $\mathrm{n}^{\circ} 1.620$ de 14 de novembro de 2011. Boletim Oficial do Estado, Espanha, n. 277, 17 nov. 2011, sec. I. p. 119046.

ESPANHA. Boletín Oficial del Estado, n.193, de 13 ago. de 1985. Disponível em: <http:// www. boe. es/ aeboe/ consultas/bases_datos/doc.php?id=BOE-A-1985-17108>. Acesso em: 19 fev. 2012.

ESPANHA. Ministerio de Empleo e Seguridade Social. Disponível em: <http://www.meyss.es/es/portada/ serviciohogar/modelos/Mod-PE-171.pdf >. Acesso em: 1 mar. 2012.

FERREIRA FILHO, Manoel Gonçalves. Curso de direito constitucional. 24 ed. São Paulo: Saraiva, 1997.

FIGUEIRAL, Eduardo Ortega. Toda Contratación Laboral. 12. ed. Valência: CISS, 2008.

GIRÓN, Martinez Jesus et al. Derecho del trabajo. 2. ed. España: Netbiblo, 2006.

GOERLICH PESET. José María et al. Contratación laboral $y$ tipos de contrato: criterios jurisprudenciales. Valladolid: Lex Nova, 2010.

JORNAL O ESTADO DE MINAS. Disponível em: < http:// www.em.com.br /app/noticia/economia/2011/12/26/ internas_ economia,269281/brasil-supera-reino-unidoe-agora-e-sexta-economia-do-mundo.shtml>

MARTINS, Sergio Pinto. Direito do trabalho. 15. ed. atual. São Paulo: Atlas, 2002.

MERCER. Consultingoutsourcinginvestiments. Disponível em: <http://www.mercer.com/press-releases/1420615>. Acesso em: 3 fev. 2012.
MOSCHIN JÚNIOR, Alberto José. Forma de Pactuação e Prorrogação do Contrato de Experiência. Revista Eletrônica da Faculdade de Direito de Franca, Franca, v. 2, n. 1, 2010. Disponível em:<http: // www. Revista . direitofranca.br/index.php/refdf/article/viewFile/63/34>. Acesso em: 2 fev. 2012.

PIMENTEL, Dinaura Godinho. Direito do trabalho e dignidade da pessoa humana: no contexto da globalização econômica problemas e perspectivas. São Paulo: LTr, 2005.

REY GUANTER, Salvador del. Estatuto dos Trabajadores: comentado y con jurisprudencia. 2. ed. Madrid: Ed. La Ley, 2007.

RODRIGUES, Américo Plá. Princípios do direito do trabalho. 3 ed. São Paulo: LTr, 2002.

SIMÃO DE MELO, Raimundo. Acidente de trabalho: responsabilidade com e sem culpa. Escola da Magistratura, São Paulo, ano 3, n. 3, 2008, p. 103.

RIO GRANDE DO SUL. Tribunal Regional do Trabalho 4a Região. RO 0021000-62.2009.5.04.0662 da 6ª Turma.

UNIÃO EUROPÉIA. Working Time Directive, 2002. Disponível em:<http://eur-lex.europa .eu/ LexUriServ/ LexUriServ.do? uri =CELEX: 32 003L0088:EN:HTML>. Acesso em: 23 jan.2012.

UNIÃO EUROPÉIA. Proteção dos jovens no trabalho. Disponível em:< http://eur-lex.europa.eu /LexUriServ/ LexUriServ.do? uri=CE LEX : 31994 L0033:pt:HTML>. Acesso em: 2 fev. 2012. 